\title{
Innovative Rural Financing In Zimbabwe: A Case Of Cattle Banking
}

David Bote, University of Fort Hare, South Africa

Stephen Mago, Great Zimbabwe University, Zimbabwe

Costa Hofisi, North-West University, South Africa

\begin{abstract}
This study breaks new ground by looking at an innovative financial approach of livestock banking vis-à-vis rural finance. The purpose of this paper is to evaluate the validity and feasibility of 'cattle banking' as an alternative innovative financing strategy in Africa with specific reference to Zimbabwe. 'Cattle banking' has entered the debate on innovative financing for rural areas. In Zimbabwe, TN Bank (now Steward Bank) has taken the 'bull by the horns' through introducing the new strategy to farmers who are mostly rural. Cattle are very important assets in the rural areas despite the challenge of climate change and global warming that have direct negative effects on pastures.

This is an exploratory paper that relies on extensive literature relating to 'cattle banking'. The authors find that 'cattle banking' has the potential to assist farmers to open bank accounts using cattle, thus encouraging them to save their assets. Moreover 'cattle banking' promotes assetbuilding among farmers. Many farmers in the rural areas of Zimbabwe do not have bank accounts because of what they experienced during Zimbabwe's "lost decade" (2000-2010) when bankers lost millions of dollars to the hyperinflation. This paper recommends that cattle banking should be developed as it has the potential to uplift the livelihoods of rural farmers. It is also seen as an innovative strategy to overcome rural finance challenges.
\end{abstract}

Keywords: Rural Finance; Innovative Finance; Cattle Banking; Zimbabwe

\section{INTRODUCTION}

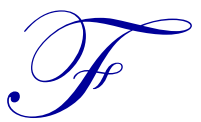

ailure to meet stringent collateral requirements significantly contributes to acute levels of financial exclusion and poverty in rural areas of developing countries such as Zimbabwe. Access to finance is broadly regarded as a catalytic metric for socio-economic development (Beck et al., 2004; Levine, 2004; Helms, 2006; Cracknell, 2012; Gimet \& Lagoarde-Segot, 2012; Assuncao, 2013). As such, innovative finance services that are cognisant of developing countries' rural circumstances and offer appropriate collateral provisions have, ideally, the potential to alleviate financial constraints and consequently improve livelihoods and socialeconomic conditions of the people. A great deal of literature on rural finance has focused on microfinance and mobile banking, which still could not cover the huge gap in financial access. To the best of our knowledge, this paper is the first attempt to explore the unconventional world pioneer livestock-based banking model, 'TN Cattle Bank', which was formally launched in 2013 in Zimbabwe. The paper is underpinned by the following principal question: "What are the prospects of this new banking model to rural finance in Zimbabwe?"

Accessing finance intermediation services at affordable, fair, appropriate, and safe terms is a huge challenge for many rural poor (Buttler \& Cornaggia, 2008; Guikinger, 2008; Togba, 2012). Particularly, collateral requirements are a major financing obstacle and lack of collateral to secure loans borrowed from formal financial institutions is often cited as a critical barrier to accessing credit loans (Campaign \& Ramahan, 2010; Rausche, 2010; Mago \& Hofisi, 2012; Mago, Hofisi, \& Mago, 2013; Chakravarty \& Pal, 2013). These inflexible requirements undermine the relevance of financial institutions to rural people and this partly explains the limited suitable financial intermediation services in rural areas. A large percentage of rural people's assets, such as land, are untitled (Field \& 
Torero, 2004) and their major assets, such as livestock, are often disregarded by financial institutions. Because of this and other factors, rural areas significantly lag behind urban areas when it comes to financial intermediation services. This has, to a large extent, led to a prolonged view that rural people are not creditworthy by many conventional financial institutions. Collateral is mainly used by conventional financial institutions as a mechanism to reduce loan defaults and delinquencies and people without proper collateral are thus regarded as risky.

In absolute terms, financial exclusion and poverty are more pronounced in rural areas, relative to urban areas in Zimbabwe. In many developing countries, relationship-based lending exists as the main alternative as many people do not possess high collateral and lack the history of creditworthiness (Cole, 1998; Schrader, 2009; Berg \& Shrader, 2012). Due to limited financial options, a large number of rural people settle for suboptimal and exceedingly expensive financial mechanisms. Most of these mechanisms are non-regulated and non-supervised such as those provided by loan sharks, rotating savings and credit associations (ROSCAS), accumulated savings and credit associations, or other hybrid forms (Koker \& Jentsch, 2013).

The remainder of the paper covers the literature review and the banking model, the feasibility and prospects of a new banking model in light of rural finance, and recommendations and conclusions.

\section{LITERATURE REVIEW}

\subsection{Case Study Background}

Zimbabwe is a southern African country that covers about 390,757 square kilometres and has an estimated population of about 12,973,808 million (Zimstat, 2012). About $68 \%$ of the people are in rural areas that are mainly dominated by agriculture (Zimstat, 2011). Poverty is direr in these rural areas, relative to urban areas, as most rural enterprises are characterised by low productivity and minimal use of advanced inputs (ibid). Zimbabwe's agricultural system is dominated by smallholder farmers who rely heavily on subsistence implements and rain-fed production. These rural dweller farm and non-farm enterprises are hugely constrained of finance. Both their poverty estimates range from 70 to $85 \%$, depending on sources, with the situation more acute in rural areas. Although there are debates over the estimate of cattle herd in Zimbabwe, estimates put it between 5 and 6 million (Sibanda, 1999). The monetary value of this herd is over US $\$ 1$ billion dollars - a significant amount that can be unlocked in value.

Zimbabwe is a country that endured one of the world's most infamous recorded hyperinflations that wrecked the nation's financial system, leading to the collapse of several banks and the depletion of people's assets. In this difficult time, banks and other financial institutions were overwhelmingly lending to high quality borrowers, not small players (Chikoko \& Le Roux, 2012). In 2008, banks stopped lending due to the tough operation environment (ibid). In order to recover under difficult circumstances, banks were charging high interest rates to loans of between 6 and 30\% (Murota, 2011). Some of the bad experiences people endured, with regard to banking, are non-availability of money in banks, restrictions on withdrawing cash from banks, enduring long and winding queues, and high bank charges and constrains in making credit purchases (Makochekanwa, 2009). For a long period, many people stopped using banks; thus, the cattle bank may be the very first bank account for these people. Only a few - mostly the formally employed and middle and upper class - Zimbabweans had the opportunity to use banking services. The situation was abated by the introduction of the multicurrency regime in 2008, which ameliorated socio-economic conditions in the country. This background points out that the majority were left out and do not have the capacity to use banking services. Transaction volumes through banks declined; thus, this model has the potential to bring in more people in the gamut of banking.

The last recorded official figure of hyperinflation was 231 million percent as of July of 2008 (Besada \& Moyo, 2008). As a result, the Zimbabwean financial system was heavily affected by the economic meltdown and was clearly witnessed in the banking system. The financial crisis led to closure and liquidation of several banks. Among the closed banks were Intermarket Banking Corporation, Royal Bank Limited, Barbican Banking Limited, Time Bank Corporation, Trust Bank Corporation, Universal Merchant Bank, and United Merchant Bank (Muvingi, 2011). This led many people to lose confidence in the banking system until 2008, and currently a substantial number of people are not yet confident of the system. The government dumped the Zimbabwean dollar for a multicurrency system that improved conditions substantially. It is also imperative to acknowledge that the recent global financial 
crisis (2007-2008) did not spare Zimbabwe, making the provision of credit even more difficult. This crisis made the need to explore alternative approaches to rural finance more urgent (Kloeppinger-Todd \& Sharma, 2010).

A large number of Zimbabweans lost faith and trust in the banking system because of the previous economic and financial crisis. To date, the country is battling with liquidity shortages (Mishi \& Kapingura, 2012). Minimal capital flow in the country contributes significantly to credit challenges (Chagwiza, 2012). Due to the stressed economic circumstances, most banks - particularly foreign - have been reluctant to advance loans to people in Zimbabwe. This has led foreign financial institutions to be riled by the government, stoking aggressiveness toward indigenising those firms. Financial intermediation services in the rural economy of Zimbabwe are consequently low (Matunhu, 2013). In the same vein, lack of collateral has been cited as a huge hindrance for SMEs' quest for loans as only about $30 \%$ out of $92 \%$ who apply for finance get it (Herald, 2013).

Many people have been relying heavily on informal forms of finance. With respect to many rural people, they get most of their finances from selling their assets, agricultural produce, and from remittances. The government has not yet granted title deeds to beneficiaries of the land reform - a huge stumbling block as banks do not accept such farmers when they apply for loans. Many financial institutions fail to recognise livestock, such as cattle, as collateral. The cattle bank is the pioneer in recognising such collateral.

Livestock is an integral part of the agricultural economy in terms of food security, manure, draught power, and transportation. Socially, cattle are a symbol of social status and are also used for cultural rituals. Cattle are recognised as a crucial asset for many rural people and it is the most valuable livestock for many, ahead of goats, donkeys, and chicken.

\subsection{Structure of Rural Finance in Zimbabwe}

Zimbabwe banking and microfinance institutions are mainly urban-based, with a few - like Postal Office Savings Bank (POSB) and Agribank, the country's main agricultural development financial institution - having limited outreach in rural areas. Due to previous financial challenges and the poor proximity of banks to rural areas, rural credit and banking was mostly done through informal financial institutions. Apart from this, these financial institutions are not much rural-oriented in their modus operandi. By and large, most of these financial institutions were falling short in meeting the credit needs of rural people. Absence of suitable financial solutions for the poor adversely impacts on both farm and non-farm based rural enterprises.

The bulk of banking and related financial institutions cater mainly for urban, peri-urban areas, and small towns in the country. The majority of their services are mainly provided in Harare, Bulawayo, Mutare, Gweru, Masvingo, and Chitungwiza. As such, availability of formal rural finance (credit, savings, insurance) across Zimbabwe's rural areas is extremely limited. Among other factors, such as transaction and monitoring costs and inaccessibility of rural areas, banks also shun rural areas because of lack of collateral (Matunhu, 2013).

The majority of people in Zimbabwe are outside a formalised financial system. Few microfinance and informal financial institutions play a key role in addressing the financial demands of rural people. In view of this situation, Cattle Bank provides a relatively flexible form of collateral for the rural folk to get loans in the country.

\section{CATTLE BANK MODEL}

Cattle bank is a livestock banking model based on cattle, hence the name cattle banking. It was pioneered by TN Bank's subsidiary, TN Livestock Trust (TNLT) as a 'paradigm shift to formal banking' that allows farmers to unlock liquidity using their livestock. Cattle owners can use their livestock as collateral for getting credit from the bank. In other words, cattle become a tradable capital - an asset that can be utilised for bank loans when the need arises. A proof of transaction is issued to owners in the form of a bank certificate of cattle deposit.

The animals are checked with experts before a transaction is finalised. In this case, the animals are vetted for diseases and are quarantined for at least two weeks before being released to join other cattle on the farm. In general, the bank does not accept unhealthy cattle. The process is finalised with farmers when they are issued 
negotiable certificates of deposit showing the deposit, breed, sex, age, weight, and value of the cattle. These certificates may then be used as collateral by the farmers when they apply for loans and the farmers may also either withdraw cattle of equivalent weight, sex, and value or trade the certificates.

TN Bank is named after the founder Tawanda Nyambirai - an acronym for this name - but was later sold to Econet Wireless who then re-branded as Steward Bank. The 'Cattle Bank' began operating on a trial basis by taking a herd of 38 cattle in September 2012, with the full-blown operations commencing in March 2013.

Cattle owners can deposit their livestock at the bank's farms which act as cattle banks. The bank is currently taking care of these cattle 'deposits' at its Featherstone farm which is about 100 kilometres from Harare. The bank is seeking to expand or get more farms due to the growth being witnessed by the bank. Essentially, the bank provides feeding, medication, and breeding. For the first two years, the cattle remain with the bank, accruing a $10 \%$ yearly interest which can be paid in cash or in the form of additional cows to the deposited herd. Currently, the interest is perhaps the highest in the country as many deposits in Zimbabwe are currently not earning any interest. Moreover, farmers can negotiate about who will own calves born during the deposit period.

Specifically, under the TN (now Steward) Bank model, cattle act as collateral against cash loans from the bank. Depositors get loans of the commensurate value of the cattle they have put in the bank and the bank keeps the cattle. Through its livestock bank branches, the bank looks after the livestock, providing supplementary feed, insurance, and medicine. Qualified experts, like veterinarians, are employed at these ranches to deal with animal diseases. The bank gains through earning a fee income from looking and growing these cattle. The bank also earns interest from people who borrow on the security of the livestock.

The bank pays to transport the animals to its paddocks dotted for care, fattening, and cross-breeding. In return, the cattle owners are issued with the bank's 'certificate of cattle deposit' as a proof of a transaction. This banking model is currently the only way owners can get monetary value for their animals without necessarily having to sell them. Figure 1.0 provides a snapshot of the bank model.

- Livestock is deposited to the bank for a certificate that can help a client to access a loan from the bank.

- Veterinary officials are used in the transaction process, mainly to assess the cattle and their value in money before a transaction is closed. Key metrics are health, age, weight, and breed.

- A cattle owner can get loans of the commensurate value of cattle deposited to the bank.

- The bank pays $10 \%$ interest per year on the value of the cattle, which can be paid in cash or additional cows.

- Owners have the option to get back their cattle after the initial two years or to leave them with the bank for longer.

- If the owner fails to repay the loan, the bank possesses the animal.

- The bank has the right to slaughter aging cattle to sell beef and replace them with cattle of the same value.

- In the event that the owner dies, a close family member takes over the payment of the loan.

- $\quad$ The bank carries out breeding programmes and (can negotiate to keep the calves of cows deposited).

Figure 1.0 Simplified Cattle Bank Model

Source: Adapted from Maposa Kennedy (June 29, 2013)

Livestock is a crucial asset for poor people around the world. Zimbabwe is an agro-based country with the majority of its populace residing in rural areas. More than $70 \%$ of the cattle in Zimbabwe are owned by small-scale farmers (Sibanda, 1999). The majority of this herd - an estimated 4 million - is owned by smallholder farmers. Zimbabwe has one of the highest cattle population densities in Southern Africa - more than twice that of Zambia, South Africa, and Botswana. The fast-tracked land reform could also contribute to the majority of the cattle being in the hands of smallholder farmers, given that about 3000000 families benefited in this programme (Scoones et al., 2011). However significantly big this herd is, cattle have not been utilised as collateral in accessing bank credit for poor people.

Credit is crucial for economies, businesses, and agriculture, but the biggest challenge for accessing credit for many people in developing countries has been lack of collateral. Many people in rural areas cannot access formal credit, mainly because they have little assets that can be attached as collateral. Most of their assets, such as land, are either communally owned or the people lack title deeds to the land they have been allocated. As such people have been unable to leverage on their assets and improve upon their livelihoods, micro enterprises, and agricultural 
endeavours. Moreover, their by-products are of huge value to the people. People can access better inputs for agriculture, relieve distress, and build businesses. In other words, this can help in improving farming and nonfarming enterprises. This banking model helps reduce the historical biases against the rural sector in terms of banking. Livestock production is crucial to poverty reduction in rural areas. Land tenure insecurity is a huge deterrent for farmers to invest and source capital from banks to develop their enterprises. In simple terms, the inability to access finance by many rural people, especially farmers, is mainly due to lack of collateral. Livestock is generally regarded as less reliable in recovering credit.

Prior to the crisis (1997-2008), Zimbabwe's financial sector was recognised as one of the most developed in Africa (Africa Development Bank, 1994). Over the past years - from 1997 to 2008 - the Zimbabwean economy has undergone a free fall, with the country witnessing negative economic growth (Muradzikwa, 2010; Robertson, 2010). The national economy contracted by more than 40\% during the 2000-2008 period (Ministry of Finance, 2012) which resulted in the fall of GDP per capita from about US $\$ 700$ to about US $\$ 290$ (ibid). Resultantly, savings and pension's assets were wiped out and unemployment and emigration shot up significantly. Correspondingly, the problem of rural financing was worsened during this period. Will this new banking model help bring back lost faith in banks and enlist the previously "unbanked"? Will this model succeed in improving financial inclusion in rural Zimbabwe?

\section{CRITIQUE OF THE PROSPECTS OF THE CATTLE BANK}

\subsection{Potential Benefits and Sustainability of the Model}

This banking model looks very sustainable in terms of the manner in which it deals with defaulting. Even if the poor farmer defaults, the bank has a mechanism to ensure that it does not lose out in the transaction. As a result, the system looks sustainable compared to other microfinance operations in which defaulting on loans may bankrupt the bank itself. In this new model, the bank already possesses the collateral. However, the challenge of disease outbreaks and other negative eventualities may be costly to the bank.

\subsubsection{Asset Building}

By using cattle for accessing credit loans, people avoid expending other various assets they possess. Many people will not resort to disposing their precious assets, especially during times of distress and emergencies. Asset building has been widely recognised as a potent poverty reduction tool, especially in terms of strengthening human and economic capabilities (Amartya Sen in Grinstein-Weiss et al., 2007). In other words, asset building theory, capability approach, and sustainable livelihood approach strongly advocates building the assets of the poor. Livestock dominant regions, such as Matabeleland provinces, have a lot to gain from this initiative.

\subsubsection{Rural Non-Farm Benefits}

This model is different from microfinance in that the Cattle Banking finance is mainly determined by the number and value of the stock. To this end, rural non-farm activities such as agro-processing and entrepreneurships (mainly the SMEs) can use their stock of cattle to raise loans for their endeavours. Under this situation, the model can help stimulate more economic activities within those rural areas. This bank can play a crucial role to the rural economy by becoming an alternative or complimentary liquidity provider.

\subsubsection{Increased Geographical Reach}

One of the reasons why banks are mainly urban based is because potential rural clients are geographically highly dispersed, which implies high transaction costs in servicing them. The cattle bank has the potential to have significantly more reach than the traditional "brick and mortar banks." Only large commercial farmers have been the target of many banks, leaving out small scale players, especially given the cost of processing and servicing small loans. Related to this issue is the fact that clients are less likely to frequent the bank for services, as the main service is credit loans. 


\subsubsection{Can it be a Boon for Farming?}

Lack of credit has been cited as a huge constraint to the possible resuscitation of agriculture in Zimbabwe once the breadbasket of Africa. The challenge has been more pronounced because over 300,000 small-scale farmers resettled during the Fast Track Land Reform Program desperately in need of finance (Zimstat, 2013). The new bank has the potential to open a new financing option for these resettled farmers who received very little support in developing their farms from the government under the difficult economic times. So far, these families cannot utilise their land to access loans from banks since they do not have legal entitlements to them.

\subsubsection{Relieves Farmers from Other Duties}

Looking after livestock - like cattle - is a huge task that requires labour year-round. In simple words, livestock caring is cumbersome. Moreover, livestock production is inherently risky, with feed, cattle rustling, animal health, and labour being major challenges for vulnerable households. The livestock bank may be of help to farmers in areas with hardships like droughts and depleted grazing lands. It may also ease the burden of care of animals by elderly people. Many people have been losing their herds to drought, diseases, and cattle rustlers. For example, more than 9,272 cattle died in Matabeleland alone in 2013.

\subsection{Potential Challenges}

\subsubsection{Cattle's Multidimensional Importance}

The Cattle Bank might be a success, but it will face competition given the many social-economic purposes of cattle in the country. The value of cattle in rural Zimbabwean communities is huge. For instance, cattle are the major source of draught power in the country (Ndlovu, Bwakura, \& Topps, n.d.). They also play a major role in bride price payments, appeasing ancestral spirits, funeral sacrifices, and as outward symbols of value and wealth in society. They are also used for tilling, cultivation, fertiliser, milking, and for other labour processes in rural areas.

\subsubsection{The Ultra-Poor Unlikely to be Covered}

The banking model will, however, not be suitable for everyone, particularly the poorest who do not possess or have the capacity to own livestock. Thus, those people will not benefit from the services of the 'Cattle Bank'. A significant number of rural people constitute this segment of the ultra-poor who hardly possess even the smallest of livestock such as goats, sheep, pigs, and chicken.

\subsubsection{Gender Ownership and Control of Assets and Cattle}

Gender is a crucial factor in the ownership and control of assets (Schmidt \& Sevak, 2006). Men generally exercise ownership and control of assets, such as cattle in many countries, and Zimbabwe is no exception. If women are to own livestock, studies have shown that they tend to have goats, poultry, sheep, and other small livestock (Fletschner \& Kenney, 2011). Correspondingly, the Cattle Bank is less likely used by women vis-à-vis their male counterparts. Furthermore, male-biased inheritance often denies women the opportunity to inherit assets such as cattle. This can be a huge hindrance for many women to fully realise potential benefits proffered by this bank. A sizeable number of women will remain credit constrained given that they also lack entitlement to land as well. Women are active and productive players of rural Zimbabwe and they are intimately engaged in the rural sector. Overall, rural finance needs to be cognisant of women's social, legal, economic, and political position in rural communities of Zimbabwe.

\section{CONCLUSION}

The foregoing suggests that Cattle Banking is a feasible rural finance model in Zimbabwe. Rural finance entails many components and the 'Cattle Bank' model presents an innovative way to compliment other models such as mobile banking, informal finance and savings. Support from the government and other agencies can help the development of this model across Zimbabwe as well as in other countries with relatively similar circumstances. The 
major recommendation is that this model should be given a chance as it covers a huge gap in financial services for rural people facing the harsh economic situation in Zimbabwe. Cattle have huge potential to boost both rural farm and non-farm sectors across the country. More work will be needed in due course to examine the implications of this Cattle Bank for rural finance as it is still premature to proffer a conclusive position since the bank is still in its infancy. This model can, in fact, be broadened to include other livestock too.

Livestock banking is more likely to be accessible to a significant number of the $70 \%$ rural people and can help them off-set financial challenges. Rural people need credit for various reasons, which are to address short-term or long-term needs. In the same vein, this banking model has the potential to harness economic growth for rural areas by building supply chains because lack of financial services constrain the viability of small and micro rural enterprises.

\section{AUTHOR INFORMATION}

David Bote is a Masters student in the department of development studies at the Univeristy of Fort Hare and his research interests include microfinance and rural development. E-mail: 200706063@ufh.ac.za

Stephen Mago is currently a Lecturer and MBA Lead Speacialist in the Faculty of Commerce, Department of Accounting \& Information Systems at Great Zimbabwe University. His areas of expertise include microfinance, development finance, entrepreneurship, local economic development, co-operatives, and research methodology. E-mail: stepmago@gmail.com

Costa Hofisi is a Senior lecturer in the Department of Public Administration at North-West University in South Africa. His research interests include public finance, public policy, and development management. Costa Hofisi, North-West University, School of Management Sciences, Private Bag X2046, Mmabatho, 2735. E-mail: costa.hofisi@nwu.ac.za (Corresponding author).

\section{REFERENCES}

1. Assuncao, J. (2013). Eliminating entry barriers for the provision of banking services: Evidence from banking correspondents in Brazil. Journal of Banking and Finance, 37(8), 2806-2811.

2. Beck, T., Demirgue-kunt, A., \& Levine, R. (2004). Finance, inequality and poverty alleviation. Crosscountry evidence. (World Bank Policy Research Working paper). 2-21.

3. Berg, G., \& Schrader, J. (2012). Access to credit, natural disasters, and relationship lending. Journal of Financial Intermediation, 2(1), 549-568.

4. Besada, H., \& Moyo, N. (2008). Zimbabwe in crisis: Mugabe's policies and failures. The centre for International Governance Innovation. Retrieved from www.cigionline.org

5. Biti, T. (2009). The 2009 mid-year fiscal policy review statement: STERP in motion. Presented to the parliament of Zimbabwe by the Hon. T. Biti M.P., Minister of Finance. Harare: Government of Zimbabwe, (16 July).

6. Butler, W. A., \& Cornaggia, J. (2008). Does access to external finance improve productivity? Evidence from a natural experiment. Paper Presented at an International Seminar held at Baylor University, USA.

7. Chakravarty, S. R., \& Pal, R. (2013). Financial inclusion in India: An axiomatic approach. Journal of Policy Modelling, 3(5), 813-837.

8. Chagwiza, W. (2012). Rejuvenating the Zimbabwean economy: The role of banks. Journal of Sustainable Development in Africa, 14(4), 183-190.

9. Chikoko, P., \& Le Roux, P. (2012). Zimbabwe commercial banks liquidity management in hyperinflation environment. African Journal of Business Management, 6(48), 11787-11796.

10. Cole, R. (1998). The importance of relationships to the availability of credit. Journal of Banking and Finance, 22, 959-977.

11. Cracknell, D. (2012). Policy innovations to improve access to financial services in developing countries: Learning from case studies in Kenya. Center for Global Development. Retrieved from http://www.cgdev.org/doc/LRS_case_studies/Cracknell_Kenya.pdf

12. Deloitte. (2010). Doing business in Zimbabwe: The jewel of Africa. September 2010. 
13. Fletschner, D., \& Kenney, L. (2011). Rural women's access to financial services: credit, savings and insurance. (ESA working paper No. 11-07). The Food and Agricultural Organisation of the United Nations. March 2011.

14. Gimet, C., \& Lagoarde-Segot, T. (2012). Financial sector development and access to finance. Does size say it all? Emerging Markets Review, 13(3), 316-337.

15. Guirkinger, C. (2008). Understanding the coexistence of formal and informal markets in Piura, Peru. World Development, 36(8).

16. Herald (2013 16 April). Zimbabwe: lack of collateral hinders SMEs. Retrieved from http://allafrica.com/stories/201304170660.html

17. Kloeppinger-Todd, R., \& Sharma, M. (editors). (2010). Innovations in rural and agricultural finance. Focus 18, International food policy research institute, World Bank: Washington DC.

18. Koker, L. D., \& Jentzsch. N. (2013). Financial inclusion and financial integrity: Aligned incentives? World Development, 44, 267-280.

19. Helms, B. (2006). Access for all: Building inclusive financial systems. World Bank: Washington DC.

20. Levine, R. (2004). Finance and growth: theory and evidence. (Working Paper). Carlson School of Management, University of Minnesota.

21. Mago, S., \& Hofisi, C. (2012). Rural finance: A strategy for reducing aid dependence for poverty alleviation in rural sub-Saharan Africa. Africanus Journal of Development Studies, 12(1), 85-97.

22. Mago, S., Hofisi, C., \& Mago, S. (2013). Microfinance institutions and operational risk management in Zimbabwe: Insights from Masvingo Urban. Mediterranean Journal of Social Sciences, 4(3), 159-168.

23. Makochekanwa, A. (2009). Clothed in rags by hyperinflation: The case of Zimbabwe. University of Pretoria.

24. Mangudya, J. (2011). Current challenges facing the banking sector in Zimbabwe and way forward. In: Conference for the Confederation of Zimbabwe Industry. Victoria Falls: Commercial Bank of Zimbabwe.

25. Matunhu, J. (2013). Rural banks for rural productivity in Zimbabwe in the 21st century. Journal of Agricultural Science, 4(1), 21-26.

26. Mishi, S., \& Kapingura, F. (2012). Women's access to microfinance and poverty alleviation in Zimbabwe: Case study of Chinhoyi town. African Journal of Business Management, 6(29), 8667-8676.

27. Murota, N. (2011). Banking institutions; market performance analysis. (Unpublished). Notes. Harare: Commercial Bank of Zimbabwe.

28. Ndlovu, L. R., Bwakura, T., \& Topps, J. H. (n.d.). The role of donkeys in integrated crop-livestock systems in semi-arid regions of Zimbabwe. Retrieved from www.atnesa.org

29. Onumah, G. E. (2002). Improving access to rural finance though regulated warehouse receipts systems in Africa. A case study paper presented at an international conference on best practice.

30. Ramahan, M. M. (2011). Access to finance and firm growth. Journal of Banking and Finance, 35, 709-723.

31. Rausch. (2010). Innovations in rural and agricultural finance; Bundling development services with agricultural finance: The experience of drumNet. Focus 18, Brief 14, July 2010. Retrieved from http://www.ifpri.org/sites/default/files/publications/focus18_14.pdf

32. Schmidt, L., \& Sevak, P. (2006). Gender, marriage and asset accumulation in the United States. Feminist Economics, 12(1-2), 139-166.

33. Schrader, J., (2009). The competition between relationship-based microfinance and transaction lending. University of Heidelberg, Mimeo.

34. Sibanda, S. (1999). Animal production and management. Module 1 CASD, 301. Zimbabwe Open University, Harare. p. 213.

35. Togba, E. L. (2012). Microfinance and household access to credit: Evidence from Cote d'ivoire. Structural Change and Economic Dynamics, 12, 473-486.

36. Zimbabwe National Statistics Agency (Zimstat), Census (2012). Preliminary Report Harare: Government of Zimbabwe.

37. Zimbabwe National Statistics Agency (Zimstat). Poverty and Poverty datum line analysis in Zimbabwe 2011/2012. April 2013. Retrieved from http://www.zimstat.co.zw/

38. Maposa Kennedy (2013 June 29). Moo-lah for Zimbabwean farmers. Mail \& Guardian. Retrieved from http://www.lifestyleholdingslimited.com/news 